623 の研究であることは, WISC が研究上や実際上の 目的からして, 重要な位置を占める検查であると同時 に, 日本版の標準化の手続きに問題を見出す人が多い ことを示唆している. これらと，1972 年の資料が示す あのを考六あわせると, この改訂に組織的に取り組む べき時期が来ていると言えないだろらか。

PPVT, EFT, RFT, MFF, VADS, ITPA はもちろ ん, KEL 検査にしても, 外国のテストが基本になって
いるが、これらが研究上や実際上の目的で有効に使用 できるようになるためには，これらがそれぞれ何を 測っているのか.そこで目標となっている概念が，他 の類似概念とどういう関係にあるのかを明らかにする とともに, 代表的で十分に大きい標本を使用し，また， 交差妥当化の努力を惜しんではならないと思う.

（丸山和夫・小嶋秀夫）

\title{
臨床・障害（701～707）
}

座長岡田明・井上厚 701 可視性ならびに可読性要因の弱視児の音読に及 ぼす影響について

国立特殊教育総合研究所岡田明 702 色の名称の学習に関する一考察

一弱視・重度精神薄弱者における事例研究—

東京都八王子福祉園 賀 来 慶 子

703 視覚障害幼児に拈ける Communication につい

ての研究 (1)

一身振り表現（その1)一

東北大学 新 谷 守

704 全盲児のイメージの変容に及ぼす諸要因 京都大学 須 田 洋 行

705 集団参加のできないろう幼児の対人行動

一その 1 治療者との対人行動一

東京都立教育研究所 $\bigcirc$ 平 田 慶子

北村洋子

706 集団参加のできないろら幼児の対人行動

一その 2 子ども同志の対人行動一

東京都立教育研究所 ○北 村 洋子

平田㢁子

707 先天性風疹症候群児の心理的特性 (II)

$\begin{array}{crrrr}\text { 琉球大学 } & \text { 斎 } & \text { 藤 } & \text { 義 } & \text { 夫 } \\ \text { " } & \text { 名 } & \text { 城 } & \text { 嗣 } & \text { 明 } \\ \text { " } & \text { 東 } & \text { 江 } & \text { 康 } & \text { 治 } \\ \text { " } & \text { 東 } & \text { 江 } & \text { 平 } & \text { 之 } \\ \text { " } & \text { O井 } & & & \text { 厚 } \\ \text { " } & \text { 前 } & \text { 原 } & \text { 武 } & \text { 子 } \\ \text { " } & \text { 平 } & \text { 田 } & \text { 永 } & \text { 哲 } \\ \text { " } & \text { 今塩屋 } & \text { 隼 } & \text { 男 } \\ \text { " } & \text { 中 } & \text { 村 } & & \text { 完 } \\ \text { " } & \text { 林 } & \text { 幹 } & \text { 男 }\end{array}$

この室での研究発表の内容は, 弱視児の音読に関す る研究 (701), 弱視・重度精神薄弱児の色の名称の学 習に関する研究 (702), 視覚障害児の communication に関する研究 (703)，および全盲児のイメージに関す る研究 (704), 以上の弱視児, 全盲児など視覚障害児 を対象にした研究と, 集団参加のできないろう幼児の 対人行動に関する研究 $(705,706)$, および先天性風疹 症候群児に関する研究 (707), 以上の聴覚障害児を対 象にした研究の, 2 群に大別された. これら群別に, 約 30 名の参加者により約 1 時間討論が行われた.

\section{I 発表と討論の経過}

岡田 (701) の発表に関して, 鈴木 (所属不明) から, (1) 提示の文章と眼との距離について一定にしたのか, 特に活字が大になれば眼からの距離が大の方がよいの ではないか. (2) 全部活字がゴチの条件の場合の結果 は，予想に反するように思われるが，などの点につい て質問が行われた. 岡田は, (1) 特に距離は一定にせず 被験者に自由で好きな距離, つまり日頃本人がやり慣 れている距離で読ませた，距離の条件よりる，むしろ 慣れの方が優先する面も考えられ，いかなる場合にも 固有のくせの傾向が強く影響していた. (2) 被験者はゴ チに慣れていなくて，全部ゴチの場合には相対的に弁 別閥がせばまる，つまり視野が全部黒く見えてくるの ではないか。このことは内省でも被験者が嫌がってい たことからも，また実際に他条件に比して本条件の結 果が悪く $5 \%$ で有意差が認められたことからもいえ る, との回答がなされた.

賀来（702）の発表について，岡田（国立特殊研）よ り混色選択に打ける色の提示順序について質問があ ク，ランダムであったと回答された．林（琉大）より の, 本被験者の色の名称の学習プロセスは普通児の幼 
児の弁别学習のプロセスと同じと考えてよいかとの質 問に対し，賀来から同じかどうかかからない，色の弁 別をした経験を特にないといら点では同じかも知れな いが，学習プロセスとしては同じではないであろうと の回答が行われた。

新谷 (703) の発表について, 岡田（国立特殊研）か ら, 論文集中の表 1 の $\mathrm{B}, \mathrm{C}$ 項目群に対する通過率にお いて普通児と視障児の間に差があり，A 項目群におい ては差がない.これは視覚障害によると解釈してよい かとの質問が行われた。新谷は， B, C 項目群は学習に よる要因を含み, そのような動作, 行動, 身振りをす る環境におかれるかどらかによって規定される．視障 児はそのような点に欠けているためであろらと回答さ れた. 岡田より $\mathrm{A}$ と B の項目群間にあまり逜いはな いのではないかとの質問に対して, B 項目群は自発 的・有意的なものであるという点で両項目群は異なる と考えるとの回答がなされたままた岡田より，(1) 身 振りによる表出と音声による表出とを表現といら面か ら関係つけけできないか, (2) 身振りが音声言語とどのよ らに結びついていくか, などの質問が行われ, 発表者 との間で活発な討論が行われた. 更に発表者自身より， 今回の研究の問題点, および将来の研究の方向につい ての発言が行なわれた。

須田（704）の発表について, 岡田（国立特殊研）か ら, 変容といら場合, 何らかの経験をした前後の比較 において変化が認められた場合をいらのではないかと の質問がなされ，須田から全くその通りだとの回答が なされた．林（琉大）より，イメージには視覚的なも のも, 触覚的なものもあり, これらの内容の変化はそ の本人にとって意味があるかないかにより，あるいは 全く偶然により規定されるし，また変化しやすさの点 でも様々であるのではないかとの質問がなされ，須田 からその通りであるとの回答がなされた．更に林から の，全盲児のイメージを捉える妥当な手段はないかと の質問に対し，須田は，元来概念形成に関心をるち， 幼児期の概念形成における感覚の重要性を検討するた めに, 盲児・ろら児を対象に研究しているとの回答が なされた。

平田（705）ならびに北村（706）の共同研究の発表 については林（琉大）より他のろう児との比較はして いるかとの質問があったが平田より他群との比較は非
常に難しいとの答があった．淑徳大の氏からセラビス トは 1 人だが何故かとの質問があった。子どすは 3 人 たけげから問題を感じなかったとの応答があった，2 人になると子どもとのラポールに問題ができるのでは ないかとの反論もあった。 また子どもの活動を遊具と の関連でどう考えるかとの質問にはトイレットペー パーやタバコの空カンを経過に応じて入れたのはよ かったとの応答があった。これからどらいら風に研究 を発展させるかとの質問ではここの「分析表」からセ ラピストの望ましい行動をひき出したいとのことで あった。

井上（707）の発表については, 岡田（特殊研）から 風疹群が S.D. が大さいが特性に応じていくつかのク ラスターにわけられないかとの質問に対しては発表者 よりその点の検討はまだ実施していないとのことで あった. 三輪（所属不明）より被験者について質問が あったが，井上より重複児は除外し単純障害児だけを 対象にした旨応答があった。 ろら児にも同じバターン の子どすがいて出来のよくない子に多いのでろら児と 風疹児との比較をしたいとのことであった．都研の氏 からは井上の研究がどのように教育現場に生かせるか との質問があったが，井上は現在は基礎的特性をとら えているので教育現場への適用は考えていない。なる べく早く総合的データをまとめ現場に生かしていきた いとの答があった。なお妊娠時期と風疹症候群児の発 生との間には関連があるので心理学的フプローチを試 みたいとのことであった。

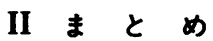

特殊教育の方法論には多様性がある. 本部問でも井 上 (707), 岡田 (701) らの実験心理学的アプローチも あれば, 賀来 (702), 須田 (704) のケーススタディも ある. 平田 (705), 北村 (706) は「関心」を重視する ので, 広い意味では社会心理学的フプローチであろう. 新谷 (703) のは調査法をとっている.どれがよいとは 言えないと思うのでどういら事態でどの方法論をとる かの選択が重要になると思われる。そ点それぞれの 研究がそれぞれの方法論でかなり深い分析を遂行して いたと思う．ただ外部からのノイズが発言を聞きとり にくく十分理解できないので批判などが十分おこない 得えない恨みは残った。（岡田 明・井上厚） 


\section{臨床・障害（708～715）}

708 構音の発達に関する研究

\section{座長 小川 再 治・藤 田 継 道}

一年齢, 知能と音弁別力との関係一

大阪府東大阪児童相談所 後 藤 サ千子

709 吃音大学生に試みたカウンセリング

青山学院大学 小 川 再 治

710 数の初期学習

一 KM における数弁別反応の形成と展開一

国立聴力言語障害センター ○山田麗子

東京大学 鹿取広人

711 構音得点の数量化について

-Articulation Proficiency Score の検討一

愛知教育大学 松下淑

712 精神薄弱児の治療教育 (1)

一言語を中心として一

$$
\text { 広島大学 船 津 守久 }
$$

713 小類症ならびに神経学的障害 (Goldenhar's

Syndrome）をむつ子の言語発達 (I)

明治学院大学 野 口 明子

714 脳性麻痷児における緊張のリラクセイション

$$
\text { 九州大学 藤 田 継 道 }
$$

715 脳性マヒ児の立位と片足立ちにおける腰線につ いて

\section{平安女学院短期大学 門 前 豊志子}

\section{I 発表と討論の経過}

（708）は，絵画式構音テストを 2〜6才の構音・聴 覚に異常ない子どもに行った. 年跲増加に伴なって誤 構音が減じ, CA との間に相関がみられたが, 誤構音数 と MA の間には相関がなかった. この研究に対しては 山下（愛知教大）より，方法論上の質問がなされただ けであった。

（709）は，吃音大学生 4 名に, 3 年半にわたりカウ ンセリングを試みた結果報告である. 最初非指示的方 法を用いたが効果乏しく，ヴンン・ライパー法（一種 の指示的方法) や AT K切かえてようやく症状が軽快 した. 質問は松尾（青学大）の, AT のやり方に関する ものだけであった. (708),（709）とも内容への質問が なかったのは，研究がかなり特殊であったためであろ 3.

（710）は，ほとんど言語を欠いた特殊学級 5 年の難 聴児に，数操作に関する指導を試みた。先ず見本合せ
法による数一絵カード分類を行わせた. 次で数弁別反 応を拡大するため，対象物を指にあてさせ，また指を 対象物にあてさせる方法などで, 大体 10 までの数が指 示できるようになった. 更に数の合成, 分解の指導に より, 初歩的な数概念の操作が可能になった. 小川（青 学大）が，対象児の知能水準をおさえるテストをして あるかを問らた所, 協同研究者の鹿取（東大）ょり, 本研究の目的は障害児教育ではなく, 子どすの数行動 を引き上げる方法を探ることにあり，知能指数は特に 問題にしていないとの回答があった。更に鹿取より, 指型をつくらせて指導した目的は，子どすの運動や認 知の発達水準に応じた運動バターンをつくり，集合， 順序関係を学習させる所にあるといら補足説明がなさ れた。

（711）は，幼児の構音能力得点 (APS) を求めるた め，幼児の自由遊び中の発語を錯音・分析した。 その 結果, 構音はほほ 6 才で完成することが示された。 た, APSの妥当性を検討する実験の結果も,併せて報 告された，船津（広島大）より，用語関係の質問があ り, 次いで後藤 (東大阪児相)より，構音の完成を APS で示せるかとの質問があった．これに対し松下は，構 音の完成をAPS で示すのではなく，6才児の $89 \%$ が APS100になったため，構音が完成したと判断したと 答えた.

（712）は精薄児の言語特性をみるため，その母音と 子音の構音を調べた. 1 音ずつテスターのいら音を反 復させる方法を用いている．その結果摩摖音の構音が 悪いこと，音の置かえが多いことなどが示された。松 下（愛知県大）から，このような児童の構音障害の定 義について質問があり，続いて後藤（東大阪児相）よ り，自閉的な子どもの場合，要素が変わってくるので はないかとの疑義が出され，船律はこのような子ども は予め排除していると答えた。

（713）は小䫛症の我が子の言語発達についての克明 な記録を報告した．親として子どもに心から賞賛を与 える方法を用い, 4 才 7 月で 51 音を発音させ得るよう になった，小川（青学大）は，絶えず被験者と一緒に いられるといら特色を，多少は科学的心理学のわくを 越えてわ良いから，方法論上の特色として生かせない かと問題を提起した.

（714）はCP 児の歩行可能群と不能群の足首の緊張 度を測定し, 可能群は歩行訓練が進むに従って,リラッ クスする傾向があることを示した。 ただしリラクゼー 


\section{教育心理 学年報 第 14 集}

ションは, 歩行の必要条件ではあるが, 十分条件では ないといら, 後藤 (東大阪児相) より, CP 児が最初来 談した時に，歩けるよらになるか見分ける方法はない かとの質問があり，藤田は成瀬悟策（九大）の作成し た評定表が参考になると答えた。

（715）は，CP 児の立位と片足立ちにおける腰線や 肩の傾きなどを調べ，特に「のり足」（重心をかけてい る足）との関係において, 詳細に論じた. 藤田（九大） が足首の緊張を考虑に入れたらどうかと質問したが, 門前は今回のテーマには含めなかったと答えた。

\section{II ま と め}

以上 8 篇の研究には, 一貫した共通性が無いので, 全体を通じての展望を行い難い.強いてをとめれば,

(A) 言語発達およびその障害に関係あるすの 6 篇 (708-713)，（B）CP 児の身体的能力に関する 2 篇 (714, 715) となろう.

(A) の 5 篇の内では, (708) と（711）にやや共通 点があるが, あとは相互の関連性に乏しい. (708)(711) は, 構音に関したもので, 前者は子どもの構音そのも のを狙い, 後者は多少方法論的な方面に関与している.

（708）は誤構音とCA，MA との関係を示唆した点で 意味がある.また (711) は，ほぼ6才で構音能力が完 成することを裏付けた点が注目される. APS の妥当性 についての検討を, 更に強化することが, 今後の課題 となろう.

（709）は, 現実に 4 名の大学生の苦悩を軽減した点
に意義があるが, 発表者が述べているように, 結果の 数量的処置で壁にぶつかっている.この点の工夫が必 要であろう.

（710）は, 基本的構想が（709）とは逆で, 現実に 困っている者を扱らために心理学を利用するのでな く, 心理学の立場から数操作を引き上げる方法を探る 一方策として，障害児を用いたるのである．目の前の 事象にまどわされず，仮説演繹的によりよい教育法を 土台から考えるためには, 今後このタイプの研究が重 要性を増すであろう．ただしこのタイプの研究は，そ の成果を教育場面に引きうつす時に, 難しい面がでて くるかもしれない.

（712）のような研究は，今までの精薄の言語の研究 の多くが，思考との関連で考察されていたため，比較 的少なかった. 研究方法は末だ素朴であるが, 今後の 研究の進展が期待される.

（713）は, 討論の場で小川がのべたような, 方法論 上の長所をのばして。けけば, ニニークな研究となるで あろう.

さて（B）のCP 児関係の（714）(715）は，前者が 集団集中訓練が緊張の除去に有効であることを示し, また後者がCP 児の「のり足」に着目して, 立位, 歩行 について究明することの可能性を示唆したことに意義 を感じる. 2 篇とも地味であるが, それぞれ独創的な知 見を含んでおり，今後の発展が期待される.

（小川再治・藤田継道）

\section{臨床・障害（716～719）}

座長 野 中実・山本公子 716 精神薄弱幼児をもつ母親の意識調査 淑徳大学 藤 田 雅 子

717 精神薄弱児の追跡的研究 (1) 高知大学 野 中 実

718 心身障害者の職業的適応について 一その 1大阪府立職業サービスセンター

719 心身障害者の職業的適応について

$$
\begin{array}{rrr}
\text { 藤 } & \text { 本 } & \text { 幸次郎 } \\
\text { 新 } & \text { 雅 } \\
\text { ○山 } \\
\text { 山本 }
\end{array}
$$

一その 2-

大阪府立職業サービスセンター

$$
\text { " }
$$

\section{I 発表と討論の経過}

藤田（716）は, 精神薄弱幼児をむつ母親の自己意識 を質問紙法により把握し，さらに障害児をるつ母親に 共通した特徵があるといら仮説に基づき， CP 幼児の 母親の自己意識と比較検討した. その結果かなり共通 の特徵が示され，また母子とも指導を受けたものはい くつかの項目で変化があった.

討論では, 野中 (高知大学) は質問項目と SCT の項 目との関連を問い, 藤田は以前にSCT を参考に加除 して作成した項目を用いたと述べた。

津村（宮城県立光明養護学校）は, 調査によって母 親の不安が増す恐れはないか, 調査のための調査に陥 らぬよらな指導方法をどうしたかを質したのに対し， 本人側から希望があれば母子ともに専門家が個別に相 
談に応じるが, 年齢により指導方法は異なると述べた。 佐藤（小林病院）は, 従来の選別する側の立場で母 子の指導は可能だろうか, 周囲の人達にまで働きかけ る必要があるのではないかと問い，藤田は障害児の治 療教育上母親の協力が不可欠であるし，家庭内に坬立 している幼児に集団場面を与えることが重要ではない かと考える. 現在のところ周囲への働きかけには限界 があり母子を重点に行っていると答えた。

野中 (717) は, 精神薄弱児が卒業後職業を含めた社 会生活にどう適応しているかをとらえ, 在学時の状況 と関連づけて指導の要点を得ようとし, 今回は予備的 に(1) 事例研究 (2) 高知市教育研究会障害児部会の 行った調查結果に基づき職場適応と IQ との関連を報 告した.

討論で藤本（大阪府立職業サービスセンター）は, 評価は誰がしたか, 評価者間のくい違いがあった場合 どうしたか，評価者の本人についての知識があったか を質し，野中は職場により異なるが本人の事をよく 知った人が評価した。 また本人について養護学級（校） 出身者といら程度は知っており, 本人の能力に応じて 評価する場合もあっただろう，いずれにしても評価の 妥当性については今後検討する必要があると述べた.

佐藤は，評価者に反抗的な態度だとさびしく見られ がちであり, 守れるかどらか等の評価方法が適当であ ろらかと問い, それに対して評価者に都合よいことが 評価がよくなる傾向が見られ，“よい適応"とは常に相 対的なるのと考えられる. 評価方法を検討してみたい と述べた.

新, 山本ら $(718,719)$ は, 心身障害者の追跡指導を 通じて彼らの職業的適応のよしあしをもたらす条件を 把握しよらとした．今回はその中間報告である.

討論では, 佐々木（宮城県立光明養護学校）は要約 （2）と（5）との間に矛盾がないかと指摘し，それに 対し (2) は学校の雾囲気や学校生活の状況がその後の 職業的適応に重要な意味をもつことを示唆し，(5）は 知能が比較的よく, 話しぶりなど健常者と変わらない 場合は，仕事も同じょうに課せられがちで，それだけ 不適応になりやすいのではないかということだと説明 した.

山田 (近畿大学) は, 普通学級出身者と責護学級(校) 出身者の学校生活の適応状況について問い, それに対 し生活史調査資料を整理検討したいと述べた。
佐々木は教師の追跡指導で適応がよくなることはな いかと質し，それに対しかかる事例がほとんどなく何 とも言えないが, 教師だけでなく他の関係者の協力を 得て追跡指導することが適応を促進する上で大切であ ると答えた。

佐藤は適応のよしあしは本人と雇用者のずれに関係 し，本人が抑圧されてもよい適応なのかと問い，それ に対し抑圧されているなら "何とかがんばろう”とい ら気持にならないだろら。本人の状態と雇用者の態度 は相互に影響しあって变わると説明した.

\section{II $ま$ と}

藤田の研究は, 精神薄弱幼児と CP 幼児の母親の自 己意識を比較検討して, かなり共通した特徵が存在す ることを明らかにし，さらに指導によって母親自身の 気持が望ましい方向に变化していくことを示した。

このことは, 障害児の教育指導は母子を切り離して 考えることはできず, 従って本人と並行して母親に対 するアプローチが重要であることを改めて示唆したと いう点で意義が大きいまた各領域における母親の心 的態度の特徵は, カウンセリング等において参考にな ろう.

野中および新, 山本らの研究はともに障害者の職業 生活の状況を主に取り扱っており，これは障害者の進 路指導, 職業相談, 雇用管理, アフタケアなどにとっ て重要な問題である.

野中の研究は, 職場での評価にあたり評価者の相違 や評価基準の客観性といら問題を残し，さらにIQ と の関連のみを取り上げた方法に難点があろう。しかし 在学時の特性と職場での状況とを比較する視点は興味 深く，また綎断的に資料を積み重ねていくことは重要 であるので, 妥当な評価方法への接近の出発点として 意義があろう。

新, 山本らの研究は縦断的なアプローチで, 障害者 と彼らを取りまく多くの人達の協力によって得られた ものである. 障害者に対する職業的適応指導に示唆す る点が大であろう.

今回の発表は 28 人の事例を取り上げたにすぎない が，実際には 100 以上の事例のアフタケアを継続して いるといらことである. 今後機会をみてそれらの資料 を整理して発表してもらいたいものである.

（野中 実・山本公子） 


\section{臨床・障害（720～723）}

座長 小林 純 一・荒 川 由美子 720 エンカウンター・グループの教育界への導入

九州大学 野 島 - 彦

721 カウンセリング面接におけるカウンセラーの自 己評価

$$
\begin{aligned}
& \text { 上智大学 小 林 純 一 } \\
& \text { 宇都宮市立今泉小学校下司昌一 } \\
& \text { 職業研究所 渡 辺三枝子 } \\
& \text { 関東学院高校 ○橋 本 幸 晴 }
\end{aligned}
$$

722 読書療法の症例報告（第 21 報）

千葉家庭裁判所大神 貞

723 臨床診断の一事例

一盗癖のある女子中学生を対象に一

$\begin{array}{crrr}\text { 仙台大学 } & \text { ○荒 } & \text { 川 由美子 } \\ \prime \prime & \text { 朴 } & \text { 沢 } & \text { 一 郎 }\end{array}$

\section{I 全体的特徽}

それぞれの発表論文が質を異にしているので, 発表 ごとに問題の焦点を切りかえねばならない，といら難 点があった. 聴衆者がかなりあった（約 40 名）が, 討 論の際, 質疑応答式になったことは, そのためである ように思われる。

参加者の熱心な傾向が重なっても, 時間が 30 分しか ないため, ほとんど討論にはならないままで終わった。 それは，上述したように 4 論文が相互に関連性がな かったためである. 発表者としても参加者としても満 足できなかったように思われる. また, 時間が超過し て外が騒がしくなり, 参加者が退場し始めたので討論 が打ち切られた。

発表者は、それぞれ自分が話したいように話したが， 制限時間を守ることができず，質問時間がほとんど残 されなかった. EG を発表した野島をはじめとして, 発 表要旨を明らかに述べようとしたが, 強調点が明確に されなかったよらに思われる. 質問者の質問内容は要 を得て問題点を突いていたので, 時間さえ十分にあれ ば，興味ある討議ができたであろう。

\section{II 発表と討論の経過}

野島 (720) は, エンカウンター・グループ (EG) の 意義と日本での形態を論文集に即して報告した. 吹田, 光岡 (都立教研) から, 一般に EG の教育界への導入は 困難なのではないか，EGのリーダーと先生との間に ギャップがある時は有害ではないか, といら質問がだ
された．核になる部分のトレーニングを行い，そこが 中心となって内部の人が内部を変えていく方法をとれ ば困難ではないし，また，トップをおさえていけば有 害にはならないといら答えがあった。 また，大阪科学 教育センターの 2 人から, 日本人には卒直に意見を出 さないという特徵があるが，EG が導入された場合, 言った方と言われた方との間に感情的にしこりが残ら ないかといら質問が出された.この点については数名 の賛意があった．野島はこれに対して，そういう感情 を突き崩していく事が必要を述べた. 橋本 (721) は, カウンセラーの自己評価の重要性について論文集を基 本とした発表を行った.これに対して，小川（千葉大） からは自己啓示と自己表現・自己暴露との相異につい ての質問が出された。自己啓示は自分を相手に伝える といら相手への方向性と問いかけがある. 自己表現は より広い概念で，自分を表現することが主体であるこ と，具体的には，カウンセラーとクライエントとの関 係の中で自分をひらいて相手に伝える事であるという 答えがあった．また野島（九州大）の，抽象的作業が 理論的にはどういら根拠があるのかといら問に対して は, 共同研究者である小林（上智大）が, 実存主義の 立場から新たに試みたものである.と答えている。（訂 正箇所：論文集 p. 568 右段 23 行目 “面” の次に “接” を入れ, p. 569 左段 10 行目 “面接の中で” の次に, “意 識を実際”を補5.)

大神（722）はまず，犯罪心理学会 (9 月末) におい て第 22 報を報告した事をことわり,読書療法の歴史的 経過を概括した，適用事例については論文集の通りで あるが，加えて面接記録がプリントされ配布された。

辻（甲南女子大）は, 図畫の選択者は誰かとたずね, 適性目録（約 400 冊から成る）の中から，大神がふさ わしいと思われるものを選んだという答えがあった。 林（琉球大）は，この事例においては，いかなるメカ ニズムが働いているのかと尋ねた。 大神は, 情動の解 発と洞察という事をあげ, 幼児期の感情やその後の体 験の投影抽出過程にふれた.ささらに光岡（都立教研） は制限時間について質問した。 それに対しては，疲労 の点からも 40 分ぐらいが限度であり,そのためには対 象者があらかじめ熟読し感想文を作製しておく必要が あると述べている. 神保（明治学院大）は, 過去に成 功例だけを報告しているか否か，失敗もあるとすれば 限界はどんな点かたずねた。 大神は，これに対し，失 敗例はわずかしかないこと, 報告は成功例にとどめて 
いる旨答えた. 限界点としては, 今のところ $\mathrm{IQ}=80$ 以 上の時, 遺伝性の精薄児の時には難かしいこと, シン ナー常用者, 不良集団所属者はその状況を変えてから 行うべきであり，思春期には適切であるとも話され た.

荒川（723）は，論文を概括し，その後治療終結後の 状況について触れ，担任教師との面接を通し良好であ る事が確認されたと補足発表した．野島からは，比較 的短期間のセラピーで終結した理由は何か. カタルシ
スに成功したことかといら問がだされ，そうだといら 答えがあった，辻は，飼い犬の死がなぜ非行に結びっ いたのか，また，肥満といらことを問題視しているが その点については再考の余地はないのか，といら問が あった。これに対して前者には，そのできごと以来母 親の戦しい統制が始まったのは，食欲抑制と一層強い 欲求と無関係ではない事，また後者については考文直 してみる旨答えがあった。

（小林純一・荒川由美子）

\section{臨床・障害（724～730）}

724 精神薄弱児の言語能力について

座長 坂 本 竜 生・東

-ITPA プロフィールについての検討一 北海道教育大学 ○入 枝 木 村 健一郎

725 縦断的方法によるダウン症乳幼児の精神発達の 特徵について

東京教育大学 池 田 由紀江

726 施設乳幼児の精神発達遅滞に関する一考察

大阪教育大学 坂 本 竜 生

727 精神薄弱児に対するオペラント技法における強 化因子価の比較 (2)

東京都東村山福祉園 鈴 村 健 治 728 オペラント原理による精神発達通滞児の発語行動 変容に関する研究

一I. 方法論の問題についてー

国立特殊教育総合研究所

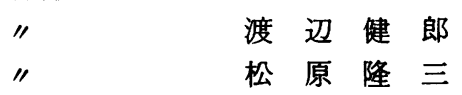

729 オペラント原理による精神発達遅滞児の発語行

動の変容に関する研究

一II. 実験結果の報告一

国立特殊教育総合研究所

$\begin{array}{rrrr}\text { 東 } & & \text { 正 } \\ \text { 渡 } & \text { 辺 } & \text { 健 } & \text { 郎 } \\ \text { 松 } & \text { 原 } & \text { 隆 } & \text { 三 }\end{array}$

730 オペラント技法に基づく重度精神遅滞児の食事

行動訓練過程の解析

愛知県コロ $=$ 発達障害研究所

正

\section{I 発表と討論の経過}

入枝 (724) は精神薄弱児に対してITPA を適用し， MA と PLA の関係, 類型比較, MA 水準による予湘性 について報告した。その結果，精薄児では聴覚音声回 路の欠陥が予想されるにも拘らず必ずしも有意な差異 が認められないこと, 類型比較も同様で, MA の高さ とも対応しないことを示した。

池田 (725) は従来のダウン氏症の研究が専ら横断的 研究に留まっている点の反省からもっと発達的視点に 立って樅断的に追跡する必要のあることを配虑して津 守・稲毛式尺度と田中ビネー尺度でダゥン氏症児個々 の発達率から 3 つの類型が見られることを報告した。 平均発達率に対応する $\mathrm{A}, \mathrm{B}, \mathrm{C}$ 群の想定から,これま で一義的にダウン氏症児の MA の発達がCAに比し て低いといら考えは改めなければならないとした。

坂本 (726) は昭和 38 年以降の 10 年間, 福岡市と北 九州市の施設乳児について津守・稲毛式による発達検 查を実施し, 逐年的変化を求めた結果, 生後 8 月 1 年 頃までの施設乳児に “中だるみ”的発達遅滞が見られ ると報告し，更に言語達滞に対する社会的刺激の強化 が施設児の総体的発達を促進するとのべた。

発表番号 727 から 730 の 4 報告は精薄児へのオペラ ソト原理適用に関するすのであった。

鈴村（727）は重度精薄児への 1 次，2 次の強化因子 価の比較を考察し，おはじき入れの作業成績の変動を 調べて因子価に関する 4 つの仮説を検討した．その結 果, 施設在園の重度精薄児にとっては 1 次強化因子よ クも 2 次強化因子の因子価が高かったが，これは知能 に関係なく社会的強化によって強化される度合が大き いからであろうとのべた。

東, 渡辺, 松原 $(728,729)$ は IQ 35,8 才の重度精薄 
児の発語行動へのオペラント条件づけの資料に基づい て, 主として教育現場での実験計画法上の問題点を指 摘した.この実験で導入した単一実験計画法 (ABAB 型）では独立変動の作用を検証するための長期観察期 が要求されるため多層ベースライン法の導入の必要性 が提唱された。

小塩その他 (730) は一連の食事行動訓練を重度精薄 児に試みるさいのタイムアウトの問題を取りあげた. 即ち, 食事訓練中のタイムアウトが 1 次刺激（食事） だけでなく，訓練者からの社会的強化刺激も排除する 機能を有することに注目し, その効果分析を行って社 会的刺激からのタイムアウト効果に関する条件統制が 必要であると結論した。

\section{II まとめ}

入枝の報告に対し上野 (旭出学園) は約 200 名の精 薄児の研究から MA とPLAの相関が高かったと発言 し, 検查者の側の影響が出やすい点を指摘した。 また ITPA による言語発達遅滞の研究を進める際に, 明確 な臨床類型の型態分析をのぞけば所謂 Educable, Trinable というような類型によるITPA のパターン を研究するのは余り意味がないのではないかという批 判を行った.これに対して入枝も実施上の問題点の多 いことを付言し，パターン分析についても，様々の角 度からの傾向を知ることが本検查法の診断的意義を昂 めるだろうとのべた。坂本はITPA の実践的効用性を 取り挙げ診断と指導の結びつき，乏しさを問うたが， 上野は, この側面での研究は現在進行中であると補足 した。

池田の報告に対しては主として研究手続きをめぐっ て質問が集中し, 渡辺（愛知コロニ一）その他多くか ら，例えばビネ一尺度と津守式尺度を併用したことの 疑問や，A， B，C群に類型化するさいに，その差がテス 卜誤差に含まれるのではないかという意見，更には東 などから A, B , C 群を分類する意味や上野が，縦断的 といらことが横断的なるのをどう否定することになる のかというような点についての見解などが問われた.
池田は本来, 尺度がグローバルであることから方法上 ではさほど問題にならないとの判断を示し, 個々のダ ウン氏症児の現実理解のためにも発達率に基つく位置 づけが必要であることを強調したが，それぞれの類型 群にどのように対応できるか, どのように発達予測が 可能かについては未だ研究が継続されねばならないこ とを指摘した。

坂本に対しては渡辺その他が “中だるみ”。意味に ついて質問があり, 更に肝心の言語発達に刺激強化が 沉化しないのを単に尺度上の問題で片付けてよいかと いら疑問が出された。更に石井（静岡大）は従来のホ スピタリズムの研究が遠隔操作などによる人格上の障 害を問題にしている点に言及し, “中だるみ”とどのよ うな関係があるのかを問い, 今日の施設症に関する研 究が当初に報告された結果と状況上でも変わっている だろうという見解をのべた。

次にオペラント条件づけを精薄児に適用していく研 究では，既にごれまで単なる治療効果に終始する臨床 報告から研究方法自体の基礎的問題を彫䵕する方向へ と変わっている動向が認められ，今回はたまたま発表 者の側から方法論上の討議を求めたこともあって討論 の内容は専ら強化因子の性格と実験計画法をめぐって 展開された. 鈴村の発達に対しては嶋田（東京学大） などから 2 次強化因子の概念に対する質問が提出さ れ，小塩その他の報告に対してはタイムアウト効果の 個人差についての疑義が寄せられた（渡辺）東などは 教育現場への実験計画導入に伴なら問題の解決につい て示唆を求めたが, これに対しては単一実験計画法の 累績使用も止むを得ないとする山口（東京学大）の見 解や多層ペースライン導入への示唆 (平井) などがあ り, その外, 観察者の信頼度や観察者の訓練をめぐる 意見が集中的に寄せられた。

全報告を包括して, 本部会においては研究を推進し ていく側の明確な方法論上の見透しの確立と, 手続き の上での正確さを求める意見の多かったことが特に注 目された。

（坂本竜生・東

正）

\section{臨床・障害（731～738）}

座長 氏原寛・五味義夫 731 言語連想検査法の臨床心理学的研究 (I)

$$
\text { 九州大学田中宏尚 }
$$

732 ロールプレイングに拈ける行動様式の考察 東京学芸大学 荻 須 隆 雄
733 情緒障害児の施設治療

一自傷行為をもつ登校拒否児（小 4 男）の一事 例一

京都市児童院青葉寮 大山経 宏 7346 年生の登校拒否児に関する事例 
735 登校拒否に関する研究

大阪市立児童院 北 村 圭 三

一親との面接経過についての考察—

東京都文京区教育センター 五 味 義 夫 736 登校拒否女子中学生（2 年）のケースについて 大阪外国語大学 氏 原寬

737 学校恐怖症の一男子大学生の治療過程と人格変 化

千葉大学田畑治

738 (発表取り消し)

\section{I 発表と討論の経過}

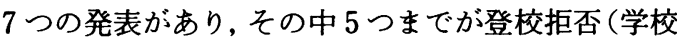
恐怖症）に関連するものであった，続く討論は，調査 法に基づく研究として, 田中（731）・荻須 (732)，小 学生の登校拒否児の施設治療についての事例研究とし て, 大山 (733)・北村 (734), および同じく登校拒否 の治療過程についての研究として, 五味 (735)・ 氏原 (736)・田畑(737)に大別されこの研究群にしたがっ て討論された。

まず, 田中の発表は, MAS (三京房版) の得点の高 い群が低い群より言語連想検査において、コンプレッ クス・サインを示す刺激語が多いであろうといら仮説 のもとに, 高校生を調查し, 両者間に若干の差（統計 的には有意差なし）をみたといら研究であった。

これに対して，川上（京大）から戸川の先行研究の 紹介とともに，臨床場面ではなぜそのような連想語が 生じたかといらことの方が重要ではないか，また結論 からの今後の方向づけについての質問がなされ，田畑

（千葉大）から臨床場面での投影法や夢との関連の問 題, 筒井（信州大）から深層心理学的概念を操作的に とらえることの限界についての意見があり，演者は今 後十分に考慮していくと回答した.

荻須の発表は，P-F スタディの項目を用いて，大学 生にロールプレイを実施し，その行動様式について分 類, その結果からロールプレイングに拈けるパーソナ リティや適応の評価基準技よび治療の手がかりを得よ らとするものであった，荻須の発表について，田畑か ら P-F スタディの本来の意図と, 非現実反応としての ロールの相違についての指摘があったが，再者間の ギャップは個々の面接でうめ合わせたいとのことで あった。

大山・北村の発表は，それぞれ施設で収容治療を 行った登校拒否児の事例を通じて，そのあり方や得失 を考察したものであった，氏原は，施設収害治療に十 分意味を見出せることを，北村の事例について述へ，
症児にとっては年齢に相応した生活体験の希薄なこ と,つまり「未熟さを生きる生活」に欠けていること, 父親の権威をどのように受けとめさせていくことなど の重要性が指摘され，北村は長期にわたる困難な事例 においては，収容治療で何が期待できるかを検討すべ きであるとともに，その困難さを訴えたかったと補足 があった。 また，过（甲南大）から，家族や学校など から解放されることに大きな意味があり，権威や統制 もポジティブな特性になっているが, 反面に施設では, 望ましい治療集団に困難ではないかとの質問があった が，大山は症児たちが連帯感をもつ場合があり，可能 との回答があった. 荻須は, 五味の研究との関連から 症児が施設を拒否する場合についての意見がだされた が，一般的には児相段階での，ワーカーの問題ですあ ると説明があった。

続いての発表も登校拒否についての研究群として討 議された。

五味は, 面接不可能な重症登校拒否中・高生の両親 との面接のみによって治療を完了した 5 事例を通し, その意義と効果を検討し，親に治療者と同一次元にお いて，家庭での生活指導を代行させていくといらこと の有効性を発表した。

氏原は，登校拒否についての研究の現状としては, 単一の理論によって総てを説明することは困難である といら観点から, 女子中学 2 年生の学校に復帰するま での詳細な面接継過について, 発表した。

田畑は, 治療人格変化がカウンセラーとクライェン 卜との心理治療関係を通じて, どのように生起してい くかを, 男子大学生の面接の逐語記録と「心理治療体 験目録」とによって考察した発表をした。

五味に対しては，林（東京教育大）からの症児の父 親への接近の具体的問題について, 辻からの治療過程 中の「学校の問題にとらわれない」ことの具体的意味 について, 田畑からの学校とのかかわり合いについて, それぞれ質問があり，補足説明がされた。

氏原の発表事例に対しては，林からカウンセラーと して登校にこだわらない心境や，転校についての質問 があり，専問家として長期的立場から多面的に考慮し て解決していくことであろらと説明がされた。

田畑の発表については, 藤原（埼玉大）から発表者 の基本的立場についての質問があり, 次いで筒井から, 学生相談における手がかりをつかめない学生の問題 や，学生からの管理体制の手先ではないかといら見方 を克服することが前提条件であるといら意見がよせら れ，演者は常に何の防衛もなく誠実に対応していく 用意があると述べ，これは，教育心理学全般に連なる 
あのであるという意見がだされた．北村からも，同様 の指摘がされた。

\section{II と め}

討論は終始活発に進められ，制限時間でやむなく打 ち切ったよらな盛況であった。

特に，登校拒否についての発表が大半をしぬ，症児

(者) と親との関係, 学校や施設との関係などの中心 的課題であり, 今後む丹念に事例研究を積み上げなが
ら解決していかなければならないことと，それは，臨 床家として, 日常の社会問題とのかかわり合い方を具 体的問題としてどうしていくかということをる今後の 問題として鮮明に浮き彫りにした印象が強かった。

とりわけ, 発表会場の外から, 教育心理学会科弾を 呼ぶ学生たちの声が聞こえる中での討論は, 参加者に 以上の課題を，今後それぞれの問題として考えていか なければならないことを切実に思わせた。

（氏原 寛・五味義夫）

\section{卸床・障害（739～746）}

座長 田口 則 良・大日方 重 利

739 精神薄弱児の動機つけに関する一研究

一施設精薄児の動機つけ特性と学習行動の関連 性をめぐってー

東北大学 今 野 和夫

740 精神薄弱児の弁別学習過程に及ぼす要因につい $\tau$

一その 1-

東京教育大学 浜 重 多美恵

741 精神薄弱児の弁別学習過程

一眼球運動を指標とした検討一

東京教育大学 前川 久 男

742 精神遅滞児の概念学習における認知的動機つけ

国立特殊教育総合研究所 田口則 良

743 精神薄弱児における概念達成過程について

一弁別逆転学習課題を用いての検討一

東京教育大学 宮 本 文 雄

744 精神薄弱児の夜体量の保存に関する実験的研究 スクリーニング及び手操作の効果についてー

東京教育大学 金子 健

745 精神薄弱児の記憶 (V)

一記憶に影響をおよぼす語の属性一

大阪教育大学 大日方 重 利

746 精神薄弱児の自由再生における媒介欠陥につい $\tau$

東京教育大学 篠 原 吉 徳

\section{I 発表と討鯩の経過}

今野の研究 739 は，施設収容精薄児を対象に Zigler の社会的剥奪仮説と学習行動との関係を検討したもの である.曾我（兵庫医科大学）から，「言語的・非言語 的社会的強化を試行間にも同様に行ったこと」の意味
についての質問がなされた.これに対して, 試行間に も強化をくり返し行ったといら意味である.とはいっ ても，強化量やその仕方を統制しなかったので成功と 無成功の各強化群で必ずしも同じとはいえず, その点 に問題が残ると説明された。

浜重の研究 740 は, 弁別学習に関して非優位次元が 適切次元のとき，精薄児は不成功に終る場合が多いこ とに着目して原因を追求したものである.この研究に は，特に質問などはなかった。

前川の研究 741 は, 弁別学習過程を眼球運動を指標 として検討したものである. 前川には寺田 (東北大学) から質問が集中した．ます，精薄児の眼球運動には年 龄差や個人差がどの程度認められるか.これに対して, 今回は 1 試行内の眼球運動の変化をとらえることに主 眼をおいたので，その点は検討していないが，以前の 研究ではいずれにもある程度の差違が認められたと回 答した.さらに寺田は, 認知能力が分節化し，言語によ る命名が可能になってくると, 図形認知に対するアイ ンシュテルングが固定化して，かえって現象的には眼 球運動が未分化な状態と同様な傾向になりはしない か, 認知発達と眼球運動との関係を調べることは考え ていないかと提案をかねて質問した。 これに対して, 第 1 ピークから optimal になる段階において，1 から 2 といら対比較数に下降してくる.このことが, 言語化 と関連があるかる知れないが，本研究では明らかにで きない.今後手続きを工夫して検討したいと回答した。

田口の研究 742 は, 認知的動機つけ手法を用いた実 験授業を行ない, 効果を分析したものである. 浜重 (東 京教育大学) から, 行動の評価の仕方について, 行動 単位をひとつひとつ評定して総計する方法の利点は何 かと質問がなされた.これに対して, 5 名の生徒を同時 に評価しなければならない実際的な必要から行った 
のであり, 特にこの方法でなければならないという利 点はないと回答した. 続いて浜重は, 事前・事後テス トで統制群より実験群の方が正答から誤答へ移行した 割合が高いのは，どのように解釈されるかと噚ねた。 これに対して，第 1 セッションで昆虫の概念の獲得が 不十分であったため, 不一致情報が与えられたことに より，それが妨害要因として作用したのではないだろ らかと回答した。

宮本の研究 743 は, 精薄児の弁別逆転学習において, 正集合とともに補集合（逆転時の正集合）に注目しな がら学習することによって逆転が促進されることを報 告している. 矢倉 (奈良教育大学) から, 非逆転学習 の場合も補集合への注目効果が認められるかという質 問があった。これに対して, 非逆転学習に関してはま だ実験をしていないので, 何んともいえないが今後研 究したいと回答した。 また大日方（大阪教育大学）か ら，精薄児の逆転学習において刺激項目を言語化させ ることによって，かえって逆転が妨げられるといら報 告ああるが, 本研究では単なる言語化でなく, 集合・ 補集合の類反応をさせることによって, 言語化が積極 的に作用したものと考えられると意見が述べられた。

金子の研究 744 は, 精薄児の保存概念の獲得につい てスクリーニングと手操作の効果を比較し, 前者より も後者の方が有効であることを報告している. 柴田(京 都女子大学) から, pretest から posttest まで時間的に 連続して行った理由について質問があった..これに対 して, 訓練が短時間のため, その効果が弱まらないら ちに test を連続して行ったと回答した. 増山（東京教 育大学）から, 実践的な行為において知覚から認識へ 至る場合と実験場面に拈いて達成される認識とは質的 に区別されねばならないこと，またスクリーニングの 効果がないことは, 精薄児では知覚が言語によって媒 介されないためであろらと意見が述べられた。これに 対して, 手操作とスクリーニングの関連を分析するこ となどによって保存概念獲得における動作の役割を明 らかにし,さらに言語の役割も追求したいと回答が あった。

大日方の研究 745 は, 精薄児の記憶の発達に関して, 語の連想的属性よりす聴覚的属性の優位性が少なくと る中学校の後半までつづくことを報告している. 吉野 (東京教育大学) から, 刺激語の選択の基準に関して, 聴覚的単位に違いがあるのではないかという質問が
あった。これに対して, 刺激語の数をある程度ふやす ために，敢えて異なるタイプの材料を加えたと回答し た.ささに吉野から，特に年少児において各刺激語を 日常そのとおりに使用しているかどらかをチェックし ておくことが必要である，また記銘の段階で各語を input したといら確認をしなければ再生時の誤反応の 位置づけがあいまいになるなどの指摘がされた。

篠原の研究 746 は, 精薄児の自由再生課題において, 記銘時に刺激項目をカテゴリー分類させるとともに, それによって記憶しやすくなることを知らせることは 群化を促進することを報告している. まず菊野（大阪 教育大学)から, 媒介過程と overt な反応の関連をどの ように考えているかという質問があった．これに対し て，認識的に分化できるといらことであり，それがさ らに performance に反映すると回答した。吉野 (東京 教育大学) は, 同じカテゴリ一名 (概念) でも年齢に よって把握の水準が異なるから, 低年龄児に対する概 念教授には特にその点を注意する必要がある，また使 われた教授条件はあらかじめ群化が起こりやすいよう にしくまれたので, その効果が実践の場においてどの ように生かされるか疑問だといら意見を述べた。これ に対して, もっと多様な条件を加えて検討したいと答 えた. それについて寺田 (東北大学) は, 精薄児が今 までどのような環境で㕕てられたかによって言語表象 の豊かさに大きな差異が生じるだろらから，このよら な条件を踏まえることによって本研究の意義が一層高 められると述べた。

\section{II ま と め}

本部門の発表内容は, すべて精薄児を対象としてい るが, 概念達成, 弁別学習, 記憶, 動機づけに関する ものに分けることができる. 寺田 (東北大学) が指摘 したように，精薄児の動機づけに関する分野は未開拓 であるが, 認知面と関連が強いあのであり, 今後一層研 究がす寸められることが期待される. また, 認知機能 は言語や動作などを含めて総合的かつ発達的に, その メカニズムをとらえていくようなアプローチる精薄児 の研究において特に必要であることも指摘された。最 後に, 最終日のため出席者が比較的少なかったが, 活 発な討論が展開されたといえる。

（田口則良・大日方重利） 


\section{臨床・障害（747～753）}

座長 篠 崎 久 五・石 井 正 春 747 精神障害に対する認知, 受容度およびその変容 東京教育大学 ○安 塚 俊 行 実践女子大学 本 田 時 雄

748 障害幼児における心理療法的アプローチの機能 と特徵 (III)

淑徳大学カウンセリングセンター

宇佐川

浩

749 自閉的傾向児の学校適応に関する研究 [II]

一指導事例の追跡と教育条件の比較検討一

$\begin{array}{lrr}\text { 静岡大学 } & \text { ○石 正 春 } \\ \text { 聖隷病院 木 村 安 幸 }\end{array}$

750 自閉的傾向児の学校適応に関する研究 [II

島田市立六合小学校 ○池 田 勝 太

751 自閉的傾向児の学習適応に関する研究 [II]

静岡県精神衛生センター ○山 城 厚 生

752 自閉的傾向児の学校適応に関する研究 [II]

静岡市立城内小学校 ○堀 内 英 雄

掛川市立中央小学校 染 葉 善 泰

静岡大学附属養護学校 柳 詰けい子

753 自閉児の学級適応について

$$
\text { 熊本大学 篠 崎 久 五 }
$$

\section{I 発表と討論の経過}

本部会での発表は 7 件あったが, 749 から 752 まで は同一のテーマについての分割発表であり, 実際には 4 件であった. しかし, 研究内容は，(1) 精神障害者に 対する偏見，（2）障害幼児の心理療法，（3）自閉児の 学級適応に関するもので, 研究方法も実験, 調査, 事 例研究といった多彩な発表内容であり, 会場には 100 名近くの参加者が集まり, 熱心な討論が行われた。

安塚・本田の発表に対して篠崎より今後の研究の方 向について質問があったが, 安塚は障害者に対する偏 見の形成過程に関心があり，幼少期にまでさかのぼっ て検討したいと答えた.ささらに受容度を高めるために 用いられたスライドの内容に関する質問には, 現状で は精神病院自体にも問題があり, 精神障害に対する偏 見の打開が容易でないと述べた。 また受容度を低める 実験条件の導入には問題があるのではないかという疑 問に対して, 実験終了後, 被験者に実験の意図を十分 説明したと答えた。

宇佐川の発表に対して，丸井（名大）は，（1）将来
の研究の目標, (2) 療法を 1 日 2 回変えて行なら意味, 組合せ方，（3）セラピストと子どすの構成について質 問した.これに対して (1) 現在の次点では事例研究の 域を出ないが，将来はどらいう子どもにどんな治療が 適しているのか明らかにしたい.（2）集中力の点で 45 分が限度でセラピストの方る疲れる. 療法を变えると フレッシュになる。なるべく異質なるのになるよう療 法を組み合わせている. (3) 子ども 7，8名にセラピス ト 5 名の割合で, 集団療法の形をとりながら, 1 対 1 の 関係からはじめていく, 療法によってその割合をふや したり，减らしたりする考えでいると答えた。 また， 各療法の状況設定は, それぞれ遊具や教具などを備え た専用のプレイルームを使用していると述べた。

平田（都教研）から，個人療法をしばらく続けた後 に集団療法に大った方がよいのではないかといら意見 が出されたが、これに対して個人療法は物理的, 経験 的理由でできないと述へ，集団的状況の方が 1 対 1 の 場合でも子ども同志のやりとりが生じることがあるの でそれを尊重したいと答えた，井上から各療法につい て，セラピストの関心や技術に差がなかったといら質 問があったが, これに対して学生のセラピストに応援 を頼まざるを得ない現状であると答えた。 さらに音楽 療法と運動療法で効果があったのはセラピスト側の要 因によるのではないかという意見に対しては,むしろ セラピーの設定が影響しており, 音楽療法では子ども たちが輪になったり, 楽器も同じすのを使い, 運動療 法では部屋が広くダイナミックな活動ができて子ども 同志の相互作用が生じやすい状況にあったと答えた。

石井らの発表に対して, 本田が一般父兄への啓蒙の 方法について質問したが，これに対して家庭教育学級 や母親学級をと扎して行っていると答えた．事例 2 の TO 児の指導をしている時に他の 3 名の情緒障害 児の指導をどのようにしているかという質問に対して は, 入級時にある程度選択しており，3名は自閉傾向の ない障害児であるため, 学級の中で他の子どもとの関 係を発展させるよう指導していると答え, 学校全体の 協力が必要であるとつけ加えた．判別委員会の問題点 と今後の方向についての質問には，委員が自閉児の実 態を知らない場合には単なる判別に終ってしまう括そ れがあり，継続的な観察に基づいた適切な判別が必要 であり,また, 教育, 医療, 福祉の諸機関が緊密な連 絡を持つことが要請されると答えた。ささらに丸井から 名古屋での実態が報告され, 固定的な入級基準を作ら 
ないように種々の症候群に対応できる柔軟な対策がと られるよらにすることと，一方受入れ側の意見を尊重 し，自閉児に対する理解を深める方法を考えなければ ならないと意見が述べられた.玉井（特教研）は，子 どもを直接みない人でもただ顔ぶれがそろえばよいと いら判別委の組織のし方に問題があることを指摘し, 山口（東芸大）は, 判別委でなく就学指導委になるべ きであると述へ，現状では理解を徐々に深める運動を 地道に行らしかないと示唆した。

野村（東芸大）は, 流動性学級について，（1）普通 学級の教科学習時での自閉児に対する指導, (2) 担任 教師とのチーム・ワーク, 責任感の問題, (3) 流動性 学級の将来性について質問したが，これに対して (1) 教科学習に対するレディネスを考慮して参加させてい る.（2）問題がある場合，校長に側面的に働らきかけ るようにしているが，むしろ通学制の方に問題がある のではないか, 情緒担任が若く、いわゆる教師ふらで ない場合はうまくいっている，(3)さらに今後実践の 中で追求していきたいと答えた.

篠崎の発表に対して, 高学年になると適応困難にな る傾向があるか, 適応群, 不適応群の CA に差がみら れるか質問があったが，全般的にCA が低く，差がな いと答えた. 本田は, IQ で分類した場合, 自閉児と精 薄児の区別はどうなるのかと質問したが，これに対し て従来, 自閉児の知能測定はタブーとされていたが, 実際に測定すると大部分のすのが遅れており, 自閉児 の知的側面を重視する必要があると述べた。ささらに不 適応行動があるから知的発達が遅れてくると考えた方
が妥当ではないかという意見に対して，不適応行動と 知能には相互関係があり，ぞちらが先かは現在の時点 では不明であると述べ，実際教育の場合，自閉児の知 的能力を把握した方が指導しやすいと答えた。

\section{II ま と}

本部会での発表内容は多岐にわたり，全体としてま とまりがないように思われるが，障害児に対する治療 教育といら点で概括できるように思われる.すなわち， 障害児を直接, 対象とした指導とその周囲への働らき かけの 2 つの面である.

宇佐川：石井ら, 篠崎の研究は, いらなれば前者に 属するもので, 宇佐川は種々の心理的治療の有効性を 克明に分析しょらとしており，従来それぞれの立場で 展開されてまた治療法の再検討を試みている．石井ら は, 日常的な教育実践の中で自閉児の学校適応のし方 を模写しようとしている．これらの研究や実践を進め る上で多くの現実的な制約があり，スタッフの養成, 入級判別などの面に論議が集中した。

安塚・本田の研究は, 後者の立場で, 障害児に対す る一般人の態度の変容について実験的に検討したもの であるが、今後さらに実践的な方向での研究が要望さ れる.

全般的に障害児を対象とした研究としては，緒につ いたばかりであり，成果を云々できる段階ではなく， 如何にして研究活動を維持し, 発展させるかといらこ とが当面の問題であるように思われる.

（篠崎久五・石井正春）

\section{臨床・障害（754～758）}

座長 小 玉 正 博・長谷川 浩 754 学生相談に拈ける行動療法の適用 (第 2 報)

一その1. 自律訓練法による不安・恐怖への グループ・アプローチー

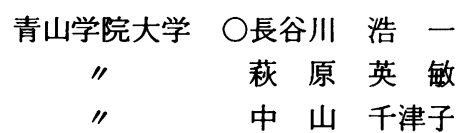

755 学生相談における行動療法の適用（第 2 報）

一その 2. 自律訓練法練習過程に及ぼす来談 者の諸要因一

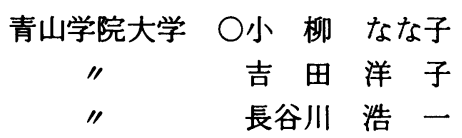

756 学生相談における行動療法の適用（第 2 報）
一その 3. 事例研究-

青山学院大学 ○清 水 幹 夫 $\begin{array}{ll}\text { " 宇田川 } & \text { 夫 } \\ \text { " 船 越 知 行 } \\ \text { " 長谷川 浩 - }\end{array}$

757 学生相談における行動療法の適用（第 2 報）

一その 4. 自律訓練法イメージを用いた脱感 作の心理生理的過程の研究一

青山学院大学 ○吉 沢 幸 夫 松尾洋一 長谷川 浩 一

758 Biofeedback による情緒障害の治療法に関す る研究 (1)

一自発性生理反応のコントロールについて一 


\section{教育心理学年報 第 14 集}

東京教育大学 ○小 玉 正 博

原 野 厷太郎

\section{I 発表と討詇の経過}

本部門では，学生相談における自律訓練法の適用時 の問題に関する一連の研究と, 情緒障害の治療に対す る新しい方法論的試みに関する基礎的研究の 1 つが発 表された.

前者については，まず長谷川（754）によって，学生 相談において集団指導による自律訓練法の指道を行な う際の有効性と限界について述べられ, 次に小柳 (755) が集団指導による自律訓練法の練習中断者についてそ の原因を分析し，指導上の要点について述べている. 更に清水 (756) は不安・恐怖症状を示す学生に自律訓 練法とイメージを使用した脱感作技法による治療過程 を事例研究によって明らかにしている. 吉沢 (757) は 自律訓練法でイメージを用いた脱感作技法について, 訓練の習熟度に伴なら心理生理プロセスの変移を検討 することによって，脱感作に怙ける弛緩の意義につい て述べている.

後者については小玉 (758)が Biofeedback 技法によ る心理生理プロセスのコントロールという側面から新 しい方法論的試みを提起し, 自発性 GSR と血管收縮 反射の $2 つ の$ 生理成分のコントロールの成否と被験者 の意識性との関連性について述べた.

討論は研究発表順に進められたが, 長谷川, 小柳, 清水, 吉沢は関連発表であったため, 一括して討論で 行われた. 討論は主として長谷川（574）が自律訓練法 の集団指導を行ったことに対して，その意味と有効性 を問ら内容のものが多かった. まず, 星野 (ICU) から, 自律訓練法のグループアプローチが個人指導と比較し てみた場合, グループ効果, 成員間のインタラクショ ンなどをねらったなどの特別の意義があるのかといら 質問があった。これに対し，個人指導との比較検討は やっていない，むしろ集団でしかやっていない，しか し, 個人指導の場合, クライエントはこの技法に対し て症状解決の意味づけを失ない，モチベーションが下 がってしまうが，グループ指導の場合には進み方や練 習の仕方を他のメンバーからフィードバックされるこ とにより，人間関係よりも AT 練習をコントロールす る意味で有効であり, むしろ個人より集団の方がよい. 沢山の学生により有効な援助の出来る方法としてグ ループでやっていく効果があると答えた。

次に小柳（755）について，小玉（東教大）から, 中 断者の 4 つの問題点の提起にどのように対処するのか との質問があったか，AT 練習とクライエントの主訴
との関わりについて十分理解させることと, アドバイ ザー自身のATに対する十分な理解とそれに基づく クライェントへの適切なフィードベックが必要である との答えがあった. 更に長谷川から, 現在, フィード バックの1つとして AT 練習効果について質問紙を 作成し色々な因子を分類しており，フィードハッックの 資料となるようにすすめているとの説明が補足され た.

また, 小川（青学大）から, 後で中断者からアンヶー 卜を取る際にカウンセリングルームと縁が切れるので 実際よりも好意的に答えていると考えられないかと指 摘があり，考えられると答えた．更に，小川は集団指 導でやるメリット，デメリットが考えられるが，中断 者については, デメリットとしておさえていけるよう なものが出ればいいのではないかと指摘した. 氏森(東 学大) から，(1) 中断者のフンヶート調査が中断後一定 期間を拀いた後にやられたのか, (2) 相談室に来たクラ イェントの症状発生からどれくらいたっているのかと の質問が出されたが，これに対して，(1) 過去 5 年間に わたっているため, フォローフップは一定でない，(2) 来談者のインテーク時の記録からはあまりよくわから ない，と答えた。

清水 (756) に対して, 自発色彩イメージで最も多く 出たのは何色かといら質問があり，色彩イメージの発 現のパターンには 6 段階あり，第 3 段階から色彩が報 告されるが，緑を報告するようになるとかなり安定し て見ていられるよらなケースが多いと回答があった。 次に田上（東教大）から，(1) 不安階層表で標準階層表 を使った意味. (2) 不安の強さの個人差は大きいのでは ないか，との質問が出されたが，長谷川は，(1) 個人別 の階層表では比較が出来ず客観化出来ないので標準を 用いた，共通性のある方が全体の流れの中でとらえら れるし, 汎化すするので, 必ずしる全項目を作る必要 はない. (2) 脱感作に入る前に, クライェントに標準階 層表の適否を確認していると答えがあった。

吉沢 (757) については, 田上から皮膚温の記録法に ついて質問があり，これに対し各言語教示を与える時 にサーミスタの目盛りを視察し，筆記したと答えた。 次に, 黙想練習の場合にも色彩, 風景のイメージまで で, その先の段階へ進めない理由がたずねられたが, これに対し長谷川は, 不安, 恐怖症状に対する逆制止 的なものが有効なので, イメージを自分でュントロー ル出来るようになっている状態を道具にして, 不安をイ メージの中でコントロールすることで脱感作を行な い, 時間的な経済性をねらっており，そのためには風 景のイメージが自由に出現する段階で十分である. イ 
メージは現実に近い刺激を準備し, 再認出来, しかも コントロールし易いという意味で，不安刺激制止に有 効と思うとの答えがあった。

次に小玉 (758) に対し, 八木 (上智大) から, (1) GSR のコントロール能力と血管収縮反射のコントロール能 力との関係, (2) GSR の陽性成分と陰性成分の機能に ついて質問があった。これに対し，(1) 生理成分として の意味を考えた場合, GSR 変化が発汗現象自体に左右 されるかなり末梢的変化を常に背景にしているため, 血管収縮反射のような循環性の反応の強さと同じレべ ルで, 反応の意識性を論じることが出来るのかが問題 となる. (2) 生理現象としての意味づけが明らかではな いが, 少なくとも, 過程の中で位相の逆転が生じたり してしまらので，実験的な設定がむずかしいといら方 法論上の問題がまず先にあげられる，と答えた。

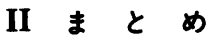

長谷川らの研究に対し，AT 綀習の集団指導につい ての問題点が幾つか指摘されたが，学生相談といら実 際場面を考虑する時, 経済的な側面からも当然要請さ れる問題でもあり，今後の研究の発展がまたれる. 更 に,イメージ・コントロールによる逆制止法の問題(清 水, 吉沢）す, 刺激コントロールといら側面から, AT 練習を行動療法の中で手段として考えていくといら意 味で注目していい観点と思われる. 同じ様に, 生理心 理的変数を直接被験者にフィードバックするかたちの Biofeedback 技法も，最近提唱されてきているAutonomic Feedback Trainig (AFT) などとの関連で, 今 後の具体的事例の中でどの様に適用出来るか, 期待さ れる.

（小玉正博・長谷川浩一）

\section{臨床・障害（759～763）}

座長 丸 井文男 - 险 山英順 759 自閉児の集団適応に関する研究

$$
\text { 名古屋大学 丸 井文 男 }
$$

760 自閉児の集団適応に関する研究

名古屋大学 細 野 純子

761 自閉児の集団適応に関する研究

$\begin{array}{crrrr}\text { 愛知教育大学 } & \text { ○佐 } & \text { 藤 } & \text { 勝 } & \text { 利 } \\ \text { 中京女子大学 } & \text { 蔭 } & \text { 山 } & \text { 英 } & \text { 順 } \\ \text { 愛知教育大学 } & \text { 神 } & \text { 野 } & \text { 秀 } & \text { 雄 } \\ \text { 名古屋大学 } & \text { 山 } & \text { 田 } & \text { 克 } & \text { 子 } \\ \text { " } & \text { 生 } & \text { 越 } & \text { 達 } & \text { 美 }\end{array}$

762 自閉児の言語発達の類型に関する研究

中京女子大学 莶 山 英 順

763 自閉児の言語発達の類型に関する研究

$\begin{array}{ccccc}\text { 愛知教育大学 } & \text { ○神 } & \text { 野 } & \text { 秀 } & \text { 雄 } \\ \text { 名古屋大学 } & \text { 丸 } & \text { 井 } & \text { 文 } & \text { 男 } \\ \text { 愛知教育大学 } & \text { 佐 } & \text { 藤 } & \text { 勝 } & \text { 利 } \\ \text { 名古屋大学 } & \text { 細 } & \text { 野 } & \text { 純 } & \text { 子 } \\ \text { " } & \text { 生 } & \text { 越 } & \text { 達 } & \text { 美 } \\ \text { " } & \text { 山 } & \text { 田 } \text { 克 } & \text { 子 }\end{array}$

\section{I 発表と討綸の経過}

口頭発表は, 発表論文集にもとついてなされ, 細野 から補足資料について次のような説明があった，論文 集にある NAGA（名大式自閉症集団適応評定スケー ル）は, I 学習態度, II 友人関係, III 教師との対人関
係の 3 スケール，10 段階によって構成されており，ま た NAUDS（名大式自閉症児発達スケール）は，(1) $\mathrm{L}_{1}$ 言語発達様式, (2) $\mathrm{L}_{2}$ 言語伝達機能と病理現象,

（3） $\mathrm{A}_{1}$ 自発性とエネルギー, (4) $\mathrm{A}_{2}$ 目的的行動と統 制, (5) $\mathrm{E}_{1}$ 固さと感情の分化, (6) $\mathrm{E}_{2}$ 感情の統制と連 続性，(7) $\mathrm{E}_{m}$ 感情の理解と関係の連続性，(8) $\mathrm{Ad}_{1}$ 大 人への働きかけ，(9) $\mathrm{Ad}_{2}$ 大人からの働きかけに対す る反応，(10）P.S. 同一性の保持, (11) St 常同行動の 11 スケール，5段階によって構成されている補助説明 があった. 討論は，(1）759〜761 (自閉児の学校適応) と, (2) 762 763 (自閉児の言語類型) この 2 群に区 分してなされた。

（1）自閉児の学校適応に関して；宇佐川（淑徳大 学）から， イ）遊戯治療形態の個別遊戯療法, 集団遊 戯療法, 集合的個別遊戯療法の組合せについて, 口) NAUDS の尺度構成に拈いて 3 段階を集団適応でき る段階は意図的に構成されたものかの 2 点について 質問があり，丸井からイ）に関しては，個別遊 戯療法から集団へといらことは現実的に行ってき ているが，集合的個別遊戯療法の位置付けに関し ては症児と治療者といら man-to-man 方式の 集合したものであり，それを経てGroupにといら方式 は特別考えていないといら説明があり，口）に関して は結果的にそうなったのであり, 初めから意図したも のではないとの回答があった，辻（甲南女子）より， 論文集 p. 648 左下の「 $\mathrm{L}_{2}, \mathrm{St}, \mathrm{P} . \mathrm{S}$. を残したままでも適 
応している.」としているが, L $\mathrm{L}_{2}, \mathrm{St}, \mathrm{P} . \mathrm{S}$. がかなりの生 活の部分を占めているケースがあると思らが，そう いったケースでも適応は良いのかという質問があり， 佐藤から， $\mathrm{L}_{2}, \mathrm{St}, \mathrm{P} . \mathrm{S}$. を残しても，良い適応を示し，残 していなくても適応の悪いヶースがあるので, $\mathrm{L}_{2}, \mathrm{St}$, P.S. と学校適応の関係は，一義的な関係がみられない といら意味であるとの説明があった。 大山（京都児童 院）より, 自閉症児の集団適応を考える際に集団の構 成を考える以前に治療のどの段階に症児がきているか によるのではないかといら質問がなされここれに対し 佐藤は, NAUDS で 4 段階, 3 段階に達しているケース でも適応の良いものも悪いものもある. 従って単純に 症児の発達段階のみで集団適応予測できず, 集団のも つ特性も考慮しなければならないであろうとした。 丸 井は, 今後, 多くのスケールとのからみ合わせによる 検討をしてみないと自閉児の集団適応にとって, 集団の 構成の問題は関与しない要因であるとは, 現段階で単 純に否定も肯定もできないと発言があり，都立教育研 究所の某氏ょり，自閉児の遊戯治療を過去何年間か行 ってきたが，その効果はあまりないように思われる. そこで個別な遊歔療法よりも幼稚園, 保育園に打ける 経験の方が意味あるように思われるが，学校集団への 適応の進歩は, 治療効果によるものか, 教育効果によ るかについての質問があった，丸井より現在の現実的 に障害幼児の集団経験の持てなさから考えると，まだ 遊戯療法によって補っていく必要性を感じていると同 時に, 自閉児幼児の段階では遊戲療法を通して, 一対 一の深い人間関係を作りあげていくと同時に, 同年龄 集団による教育と両面が必要であるように思う，また 本報告における学校集団適応の発達は, 遊戯治療の効 果のみ，および学校教育の効果のみによると明確に区 別しがたく遊戲治療のみで良いとは考えていないと説 明があった。

（2）自閉児の言語類型に関して；国分（新潟大）か ら，言語に関する訓練的な治療は行っているのかに ついて質問があった，丸井，神野から言語の訓練的な ものは行わず，対人関係の発達を中心とした遊歔治 療で行なってきているのみであると回答された。ささら
に国分から，オペラント条件付けのような事はしてい ないといらことだが, コミュニケーションの中におけ る方法は教えていく必要があるのではないかと意見が のベられ，神野は事例の内には，言語を持っていても 話さないケース, 言語を持っていなくて話さないケー スとあり, その違いは, コミュニケーションする気持 を持っているかいないかであり， $\mathrm{L}_{1}$ 型は，言語を持っ ていなくて話さない, $\mathrm{L}_{2}$ 型のようにェコラリアたけけに なっても, 治療者との関係のなかで, コミュニケート しているケースであるので, 対人関係の内で意志を伝 達していく気持をるたせる治療は必要であると述べら れた. 蔭山から，言語があっても独語のみのケースに ついて, 対人関係における治療を中心とした遊戯療法 により言語の面での改善が見られる事の説明があっ た. 宇佐川 (淑徳大学) 自閉症児の言語研究の将来の 方向性についてどら思らかと質問があり, 丸井から本 研究は従来の kanner 型, Asperger 型といらのにこだ わらずに, 発達過程からの類型化といら新しい視点で の研究の 1 つであり, 症候群によって類型化を考えて いる. 従って, 発達の多面かつ全体的なもので類型化 を考えており,言語だけにとらわれているのではない. 石井 (静岡大), 池田 (島田市立六合小学校) 上り, 言 語のない自閉児と, 発達性失語症を区別していくには NAUDS ではどのように考えるかと質問があり，䔖山 より $\mathrm{Ad}_{1}, \mathrm{Ad}_{2}, \mathrm{Fm}$ によって, 言語がなくても対人関 係におけるかかわりのあり方が異なっているので鑑別 診断はできると説明があった。

以上，参会者は約 40 名であり，質疑討論は，かなり 活発であった.

\section{II ま と め}

現今の自閉症児に関する治療実践は, 全国的に底辺 が拡大し, ことに, 障害児の教育に関する社会的要請 がつよまっており, 就学期以後の集団適応の問題は, 重要な課題である. しかし, 治療教育の分野の臨床心 理学的方法が, まだ, 未分化であり, 今後, 一層の研 究の推進が示唆されることが参会者の間で確認され た。（丸井文男・蔭山英順） 